\title{
Design and Validity of Interactive Multimedia Based on Cognitive Conflict on Static Fluid Using Adobe Animate CC 2019
}

\author{
Muhammad Dhanil, Fatni Mufit ${ }^{\text {a) }}$ \\ Physics Education Study Program, Universitas Negeri Padang, Padang, Indonesia \\ $\bowtie:$ a)fatni_mufit@fmipa.unp.ac.id
}

\begin{abstract}
This study aims to produce valid cognitive conflict-based interactive multimedia. This study uses the Plomp development model, which reports the results of the preliminary study and the prototyping phase. In the preliminary phase, five journals were analyzed and data were collected through teacher questionnaires. In the prototyping phase, multimedia is designed and selfevaluation is carried out and data collection is carried out through expert review questionnaires. The results of the journal analysis show that students' misconceptions about static fluid material are quite high. The results of the questionnaire show that learning is still teacher-centered, and interactive multimedia teaching materials are not yet available that can improve understanding of $4 \mathrm{C}$ concepts and skills. Based on the results of the preliminary research, in the prototyping phase, interactive multimedia based on cognitive conflict was designed using the Adobe Animate CC 2019 application. Interactive multimedia was arranged according to 4 syntaxes of cognitive conflict-based learning models, namely activation of preconceptions and misconceptions, presentation of cognitive conflicts, discovery of concepts and similarities, and reflection. Each syntax is designed to improve students' conceptual understanding and $4 \mathrm{C}$ skills. The results of the interactive multimedia prototype self-evaluation obtained very good criteria. The results of the prototype validity test obtained a very valid category. Interactive multimedia has been valid in material substance, learning design, visual communication display, and software utilization.
\end{abstract}

Keywords: interactive multimedia, cognitive conflict, misconceptions, static fluids

\section{INTRODUCTION}

The advances in technology and science in the 21 st century affect various aspects of life. This situation encourages people to improve their skills in the face of increasingly intense competition. Today's skills in strengthening human resources are critical thinking, communication, creativity, and collaborating skills (Wijaya 2016). Education has a significant role in improving skills in the $21 \mathrm{st}$ century. Understanding concepts and skills in the 21st century, better known as 4C skills (Critical Thinking, Creative, Communications, Collaboration), are demanded in today's education world. The government has tried to improve these skills through the implementation 2013 curriculum. Studentcentered learning in the 2013 curriculum will encourage students to understand the concept and master 4C skills (Zubaidah 2016). In meeting the demands of mastering these skills, facilities and infrastructure are needed for students to learn. 
Understanding the concepts and skills of $4 \mathrm{C}$ students can be improved in various ways through teaching materials. Teaching materials serve as learning resources, communication tools, and information sender used in education (Kemendiknas 2010). The use of exciting teaching materials can bring attention, feelings, thinking power, imagination, and motivation to study (Widada 2018). The teacher can realize student-centered learning activities through interactive multimedia. Interactive multimedia is a teaching material that combines various media and allows interaction between students and the teaching material.

There is much software that teachers can use to create interactive teaching media. One of them is Adobe Animate CC. Adobe Animate is a multimedia software that is useful for creating animations (Green \& Labrecque 2017). Formerly this program was called Adobe Flash from Adobe Systems. Adobe Animate is an update from previous versions. Adobe Animate is used to create vector graphic designs and animations for television projects, online videos, websites, web applications, internet applications, and even video games. In addition, this program also supports raster graphics, text, audio, and video embedding, and Action Script. This software is designed to design interactive and dynamic (Green \& Labrecque 2017). Also designed for reliable and lightweight two-dimensional animation projects. So that it becomes one of the recommended software for making interactive teaching media.

Interactive multimedia will enable students to learn independently. Learning like this will encourage students to understand concepts and improve skills $4 \mathrm{C}$ through the learning process they go through directly. Interactive multimedia can enhance critical thinking skills (Festiyed 2019). So, the use of interactive multimedia encourages student-centered learning, and this is by the 2013 curriculum. The ideal conditions that occur in the field are not by the demands of the 2013 curriculum. Based on the results of the analysis of a physics learning questionnaire, namely (1) physics learning is still teachercentered, (2) interactive multimedia is not yet available, (3) it is not yet available to use a particular learning model to overcome misconceptions. The observation of physics learning shows that the students' 4C skills are low. Data from journal analysis showed that understanding student concepts in static fluid material is relatively low.

TABLE 1. Percentage of students' conceptual understanding of static fluid material in five journals

\begin{tabular}{lccc}
\hline \multicolumn{1}{c}{ Journal } & $\begin{array}{c}\text { Understanding } \\
\text { Concepts }\end{array}$ & Misconceptions & $\begin{array}{c}\text { Not Understanding } \\
\text { Concepts }\end{array}$ \\
\hline Journal 1 (Yudhittiara et al. 2017) & $16.7 \%$ & $37.21 \%$ & $44.42 \%$ \\
Journal 2 (Wartono et al. 2017) & $21.6 \%$ & $40.1 \%$ & $38.3 \%$ \\
Journal 3(Prastiwi et al. 2018) & $13.4 \%$ & $57 \%$ & $29.2 \%$ \\
Journal 4(Saputra et al. 2019) & $17.8 \%$ & $64.7 \%$ & $17 \%$ \\
Journal 5 (Wahyuni 2019) & $21.8 \%$ & $43 \%$ & $38.9 \%$ \\
\hline
\end{tabular}

Data in TABLE 1. Displays student misconceptions higher than understanding concepts in a static fluid material. The teacher can do one solution to overcoming learning problems by designing interactive multimedia based on cognitive conflict. Interactive multimedia contains a cognitive conflict-based learning model with four syntaxes, namely (1) Activation of preconceptions and misconceptions, (2) Presentation of cognitive conflict, (3) Discovery of concepts and equations, (4) Reflection (Mufit 2019). Interactive multimedia based on cognitive conflict encourages students to find concepts, think critically, think creatively, communicate, and collaborate. The interactive nature of interactive multimedia allows students to type answers, choose answers, carry out experiments, and get feedback from interactive multimedia. The advantage of the cognitive conflict-based learning model is its ability to remediate misconceptions and improve students' understanding of concepts (Mufit 2018). This research aims to design interactive multimedia based on the cognitive conflict in improving students' understanding of concepts and $4 \mathrm{C}$ skills on static fluid material.

\section{METHODS}

This study uses the Plomp development model. The Plomp development model has three steps, namely (1) preliminary research, (2) prototype phase, (3) assessment phase (Plomp 2013). This research is limited to the preliminary stage of the research and prototype phase. The prototype phase consists of instrument validation and product validation. The primary purpose of this study is to find out the results of the validation of products. 
The preliminary research stage was conducted by disseminating physics learning questionnaires to three teachers of senior high school (S.H.S.) 1 Padang. Indicators of questions asked are:

1. The use of teaching materials used.

2. The implementation of experiments.

3. The use of supporting facilities and infrastructure.

4. The problem of online learning in the COVID-19 pandemic - observation of $4 \mathrm{C}$ skills in learning physics using observation sheets.

In addition, the analysis of students' conceptual understanding of static fluid material through the study of five journals on understanding student concepts in a static fluid material. In the prototype phase, interactive multimedia is designed based on needs analysis results at the preliminary research stage. Interactive multimedia is designed to work on smartphones, allowing users to type answers, select answers, and conduct virtual experiments. After the interactive multimedia is completed, selfevaluation is done and continued with an expert's review. Self-evaluation is done by re-examining the interactive multimedia created. Three expert lecturers conducted validation of assessment instrument sheet and for product validation taught by five physics lecturers at the Faculty of Mathematics and Natural Sciences Universitas Negeri Padang.

Instruments at the development stage are self-evaluation instruments, assessment sheet validation instruments, and interactive multimedia validation instruments. Interactive multimedia validation instrument sheet is prepared based on ICT-based teaching material development guidelines. There are four assessment indicators in ICT-based teaching material development guidelines: material substance, learning design, visual communication display, and software utilization. These assessment indicators are developed into several questions on each indicator.

Data processing in preliminary research was conducted with questionnaire analysis and journal analysis of students' conceptual understanding of static fluid material. Data analysis techniques on teacher questionnaire instruments are shown in descriptive analysis. The study of the knowledge of static fluid concepts in the group into three categories of understanding, namely concept understanding (U), misconceptions (M), and not understanding concepts (N.U.). Preliminary research results in descriptive analysis and percentage of student concepts in a static fluid material.

The assessment instrument sheet used is in the form of a questionnaire with a Likert scale. An assessment instrument with a Likert scale can measure a person's attitudes, opinions, and views (Riduwan 2012). The Likert scale used consists of five categories, namely a) value $5=$ strongly agree, b) value $4=$ agree, c) value $3=$ sufficient, d) value $2=$ disagree, e) value $1=$ strongly disagree. Data processing used in self-evaluation uses a formula:

$$
\text { Score }=\frac{\text { Scorefrom rater }}{\text { Maximum score }} \times 100 \%
$$

The results of the assessment of the validity of the instrument sheet and the validity of interactive multimedia are processed using the formula V Aiken's, namely.

$$
V=\frac{\sum \text { Scorefrom expert }- \text { The lowest sc orein category }}{\text { Number of categories(Number of expert }-1)}
$$

The validity value is defined using Aiken's $V$ index with a range of 0 to 1 . The following product validity index is shown in TABLE 2. Products created can be used in valid category ranges and are very valid.

TABLE 2. Product validity criteria (Retnawati 2016)

\begin{tabular}{lll}
\hline No. & Validity Index & Category \\
\hline 1 & $\mathrm{~V}>0.4$ & Less \\
2 & $0.8 \geq \mathrm{V}>0.4$ & Valid \\
3 & $\mathrm{~V}<0.4$ & Very Valid \\
\hline
\end{tabular}




\section{RESULTS AND DISCUSSION}

\section{Results}

Based on the problems in the preliminary research, it is continued to the prototype phase stage. The final result is an interactive multimedia prototype in an android application and contains a learning model syntax based on cognitive conflict. The interactive multimedia design is shown in the following figure.

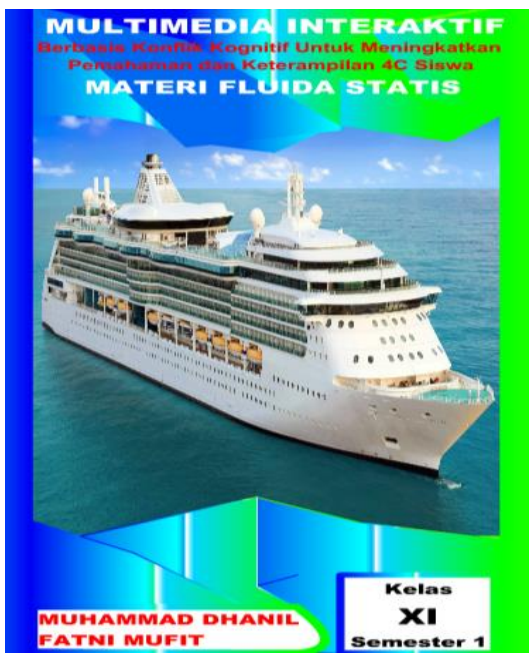

(a)

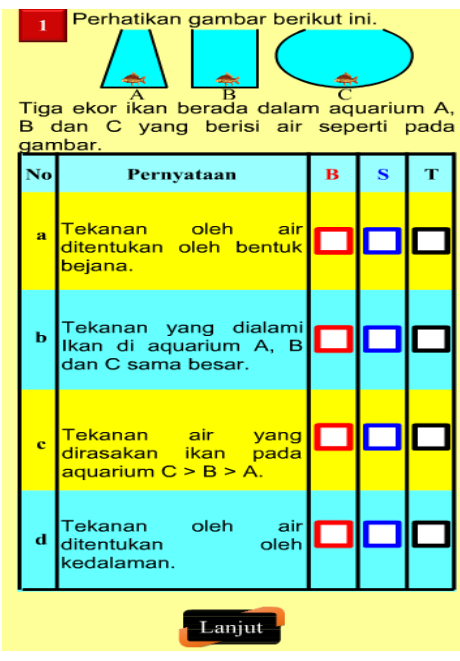

(b)

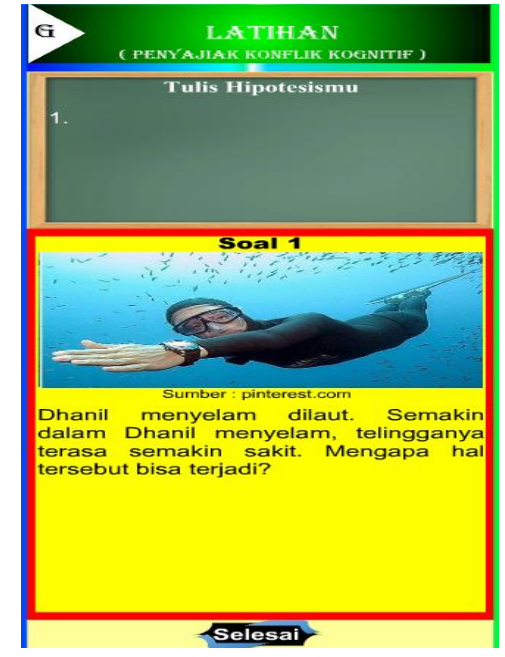

(c)

FIGURE 1. (a) Display of cover, (b) Display of Activation of Preconception and Misconception, (c) Display of presentation of cognitive conflict

FIGURE 1(a) shows an interactive multimedia cover view. The cover view consists of a title, author, class, and semester. FIGURE 1(b) is the first stage of the cognitive conflict-based learning model: preconception activation and misconceptions. The second stage is the activation of preconceptions and misconceptions that aim to know the student's initial understanding before learning. FIGURE 1(c) is the presentation stage of cognitive conflict. At this stage, students are presented with questions that cause conflict in mind and are instructed to type hypotheses. The third stage is the discovery stage of concepts and equations 

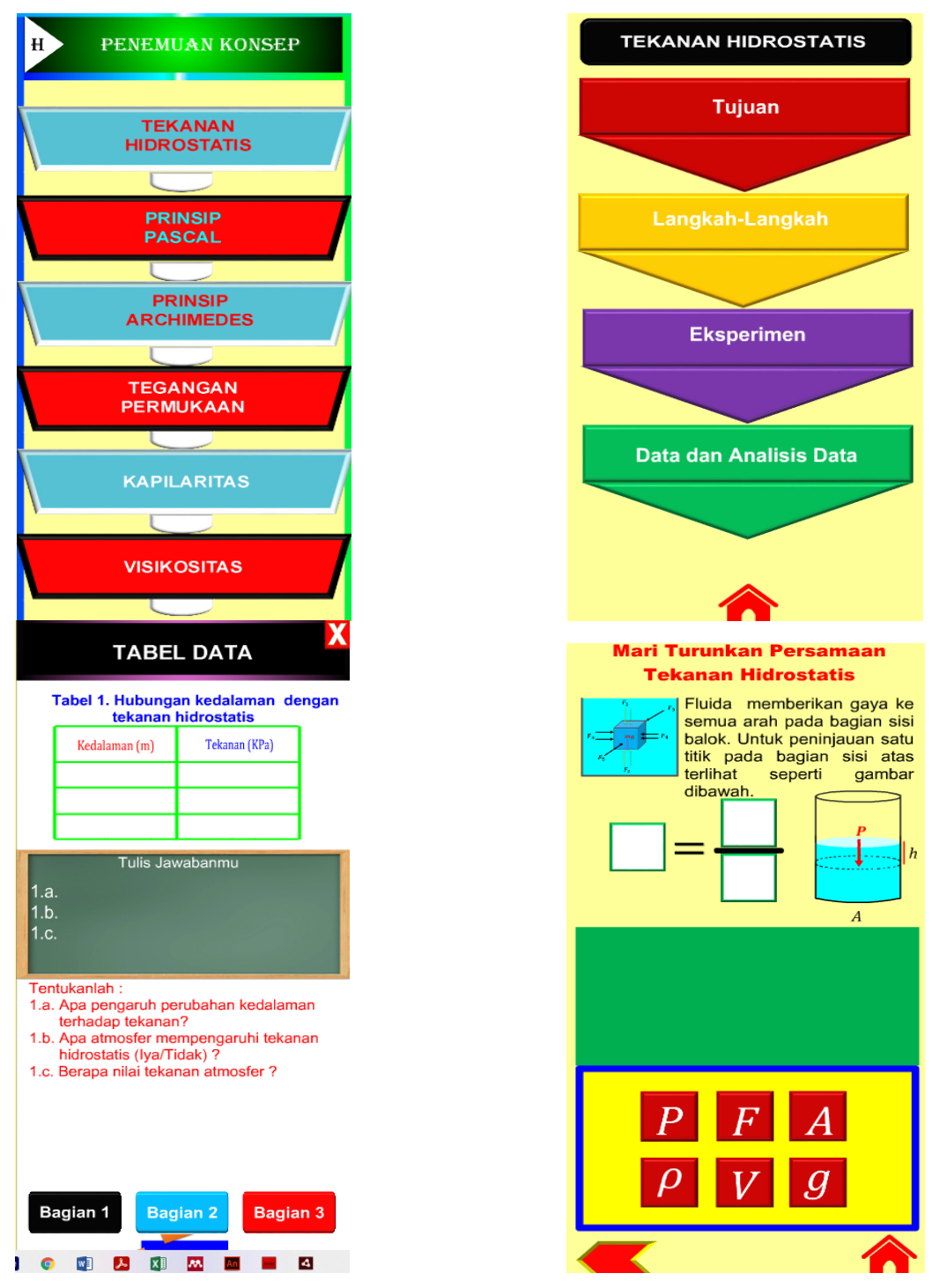

FIGURE 2. Display of discovery of concepts and equations

FIGURE 2 is the discovery stage of concepts and equations. The concept and equation discovery stage are designed to find ideas and equations independently through experimental activities. Furthermore, students are guided to derive the formula by filling in the empty boxes until they find the final equation. Phase four is the reflection stage. The reflection stage is displayed on interactive multimedia can be seen in FIGURE 3.

Interactive multimedia is structured based on a synth of cognitive conflict-based learning models. The activation stage of preconception and misconception in interactive multimedia presented a phenomenon to activate the student's initial knowledge through the choice of answer statements such as FIGURE 1(b). Cognitive conflict is presented in static fluid anomaly questions at the presentation stage of cognitive conflicts, such as FIGURE 1(c). Students write down the hypothesis of conflict presented in interactive multimedia. Cognitive conflict experienced by students is proven at the stage of the discovery of concepts and equations. Students conduct proof through experimenting activities and collect data such as FIGURE 2. Next, students concluded the findings from the cognitive conflict stage and conducted evaluation tests at the reflection stage, such as FIGURE 3. 

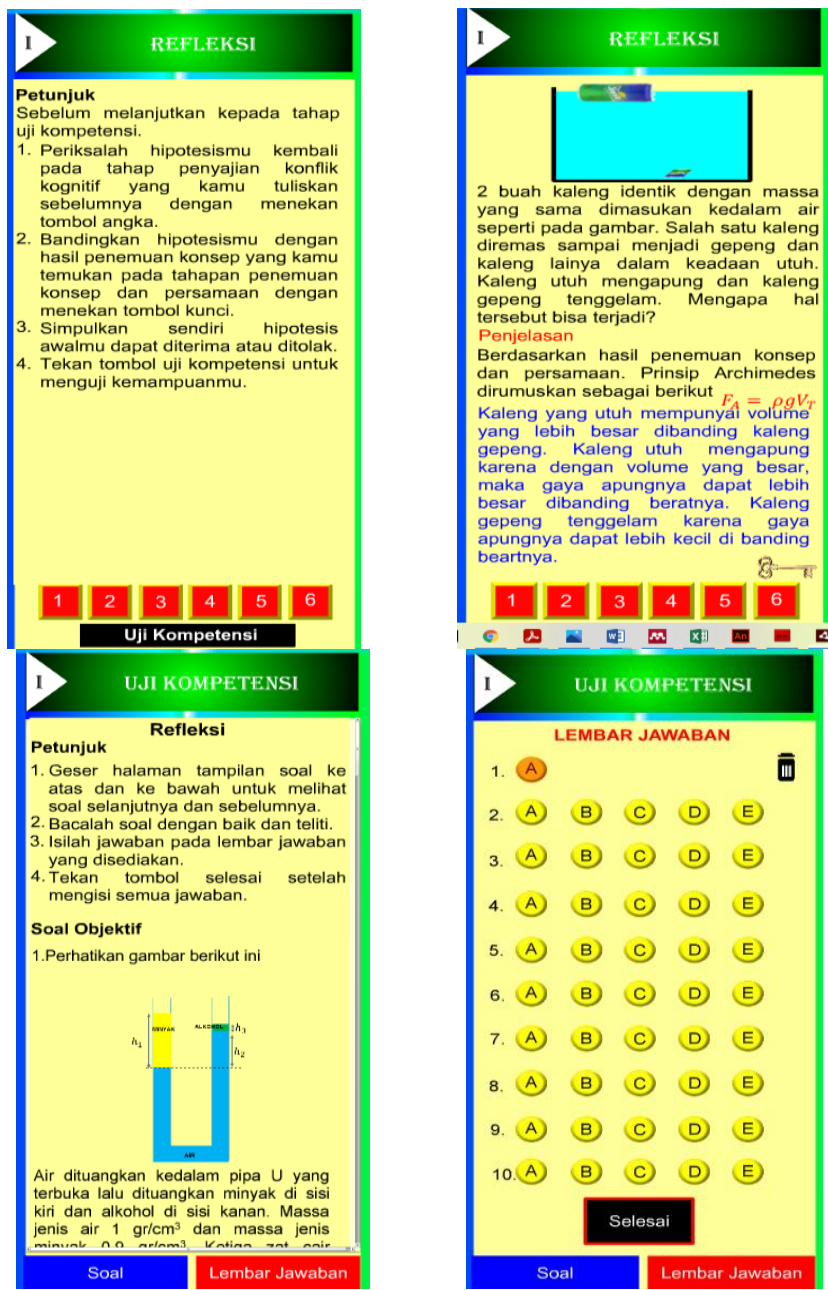

FIGURE 3. Display of reflection stage

Interactive multimedia prototypes that have been created by self-evaluation and expert review. Selfevaluation is carried out on six indicators, namely (1) interactive multimedia structure by the new development of ICT-based teaching materials, (2) syntax cognitive conflict-based learning model, (3) integrating virtual laboratories, (4) language, (5) display, (6) software utilization. The results of the self-evaluation are shown in FIGURE 4.

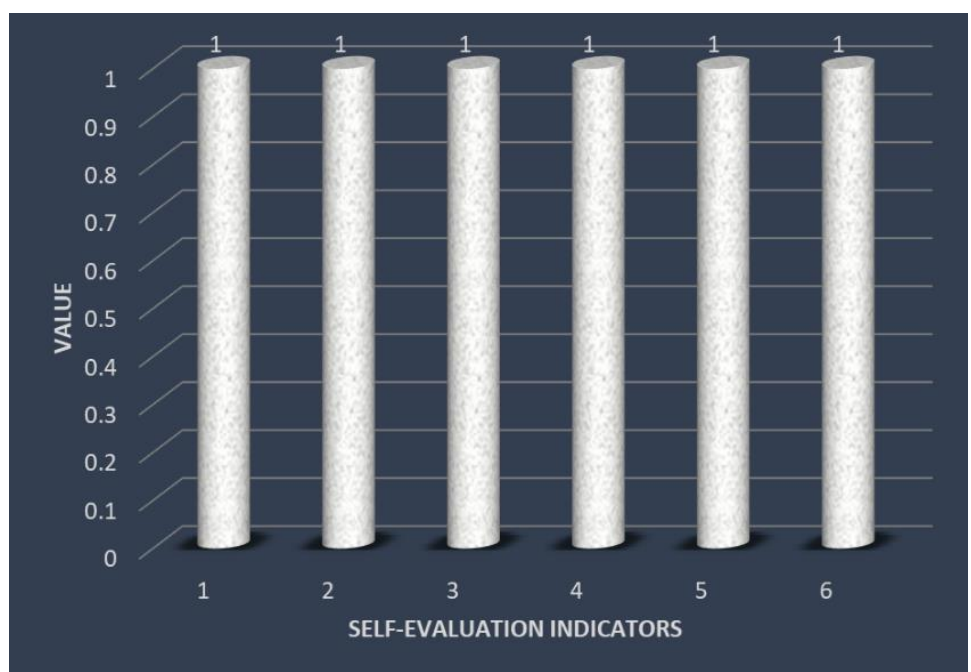

FIGURE 4. Self-evaluation result 
Based on FIGURE 4, the results of self-evaluation that researchers classify as very valid can be seen. The overall value on each indicator is 1 , with a very valid category. Furthermore, an expert review is conducted to validate instrument sheets and interactive multimedia products. The instrument assessment sheet has eleven indicators, namely (1) validity instruments can measure the validity level of teaching materials, (2) this instrument has clear instructions for use, (3) instruments are easy to use in the assessment process, (4) instruments can measure the validity of the substance of the matter in teaching materials, (5) the instrument can measure the validity of the display of teaching materials, (6) instruments can measure the validity of learning designs on teaching materials, (7) instruments can measure the validity of software used in teaching materials, (8) the instrument has feedback on the results of the assessment, (9) the size and type of instrument writing can be read clearly, (10) the display of instruments is arranged systematically, (11) the way the instrument is written is consistent. The results of the instrument sheet validation are shown in FIGURE 5.

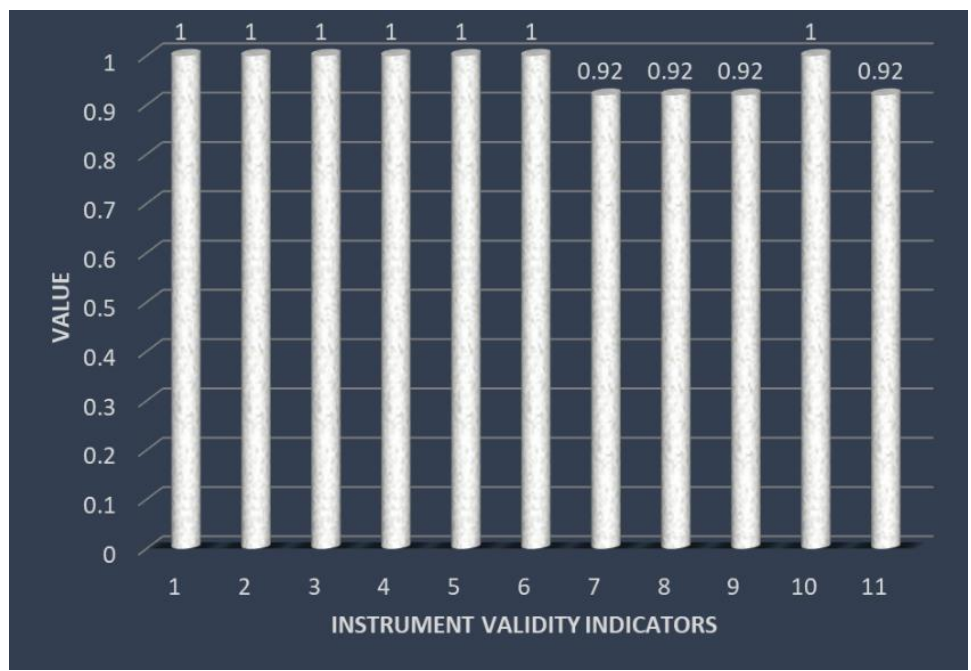

FIGURE 5. Results of instrument validation.

Based on FIGURE 5, the validation results of the instrument are in a perfect category. Furthermore, the instrument is used to assess interactive multimedia products. Interactive multimedia validation tests by experts are conducted against four indicators, namely (1) material substance, (2) learning design, (3) visual communication display, (4) software utilization.

First, the substance component of the material consists of ten indicators, namely: (1) material presented in interactive multimedia by the essential competencies, (2)the substance of the material presented is correct and complete, (3) the physics equations presented are right, (4) the physics symbols used are right, (5) the terms of physics used are right, (6) the concept of physics presented is correct, (7) images, the video, and the animation shown are by the material, (8) the material is presented in interactive multimedia by the development of science, (9) sentence writing in interactive multimedia is by the rules of a good and correct indonesian language, (10) the language used is easy to understand. The plot result of the value data of each graphing indicator is shown in FIGURE 6.

FIGURE 6 shows that the indicator value of the material substance ranges from 0.75 to 1 . Five are classified as very valid based on the ten indicators. The value ranges from 0.85 to 1 , and those classified as valid, from 0.75 to 0.8 . The average validation value on the material substance indicator is 0.86 . Thus the validation value of the material substance is classified as very valid. 


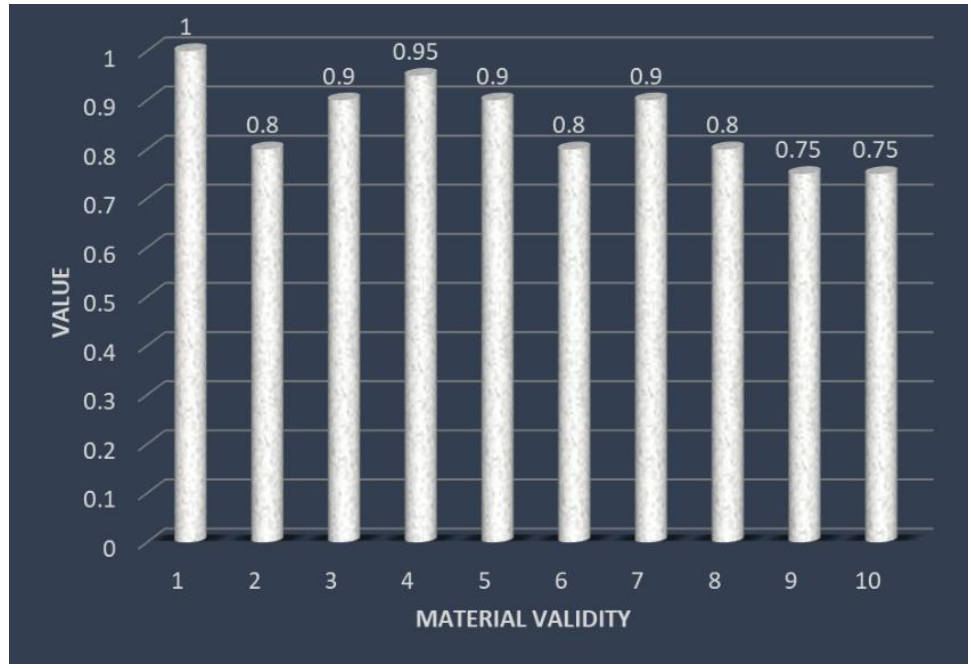

FIGURE 6. Substance validation results

Second, the learning design component which consists of 20 indicators, namely 1) the titles presented in interactive multimedia are in accordance with the material, 2) the formulation of core competencies in interactive multimedia is in accordance with content standards, 3) the formulation of essential competencies in interactive multimedia is in accordance with content standards, 4 ) the indicators presented in interactive multimedia are in accordance with essential competencies, 5) learning objectives in interactive multimedia are in accordance with the indicators, 6) interactive multimedia already contains the syntax of cognitive conflict-based learning models appropriately, 7) presenting preconception activation stages and misconceptions in interactive multimedia can reveal knowledge students, 8) the presentation of the cognitive conflict presentation stage in interactive multimedia can trigger students to think deeply, 9) the presentation of the discovery stage of concepts and equations in teaching materials can lead students to find concepts, and the equation 10) the presentation of the reflection stage in teaching materials can reveal the progress of understanding students, 11) integration of the virtual laboratory in interactive multimedia is correct in achieving an indicator, 12) the material presented in interactive multimedia is in accordance with the learning objectives, 13) the sample questions in interactive multimedia are suitable for the achievement of learning indicators, 14) practice questions / tests / simulations in interactive multimedia are suitable for the achievement of learning indicators, 15) interactive multimedia facilitates the occurrence of a creative thinking process (creativite thinking) creates basic ideas / concepts for students 16) interactive multimedia facilitates communication in expressing oral and written ideas for students, 17) interactive multimedia facilitates collaboration between students, 18) interactive multimedia facilitates the critical thinking process for students, 19) the identity of the compilers in interactive multimedia is correct, 20) every reference in interactive multimedia is listed in the bibliography. The results of the value data plot of each graphic indicator are shown in FIGURE 7.

FIGURE 7 shows that the indicator value in the substance of the learning design ranges from 0.7 to 1. Based on the 20 indicators, 14 are classified as valid, ranging from 0.85 to 1 , and those classified as valid, from 0.7 to 0.8 . The average validation value on the material substance indicator is 0.87 . Thus the validation value of the material substance is classified as very valid. 


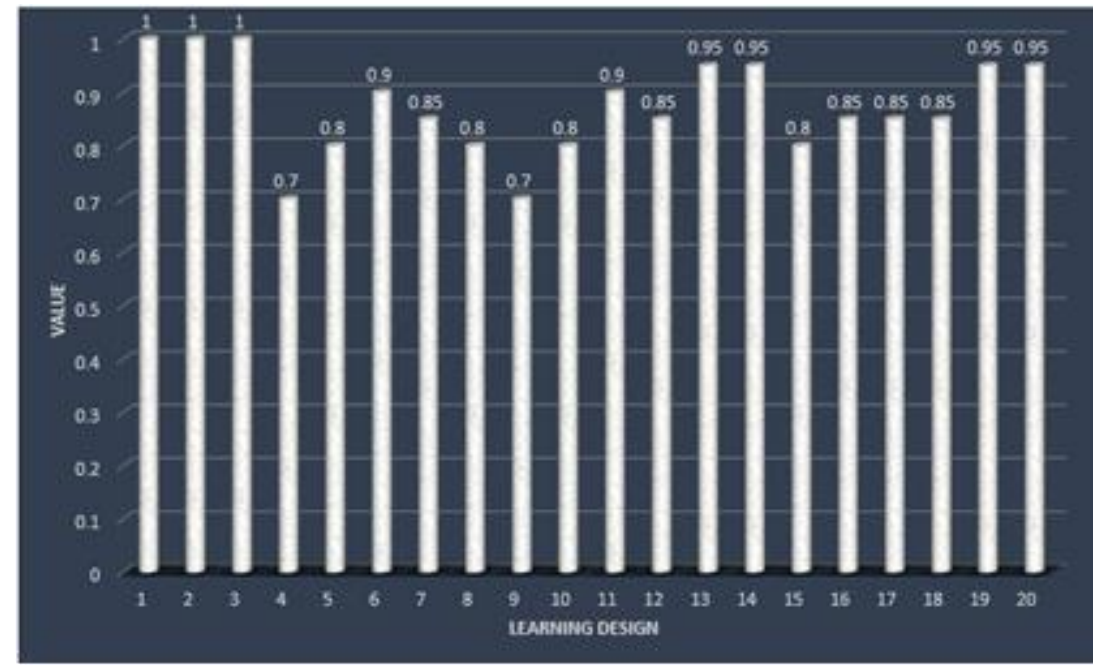

FIGURE 7. Learning Design Validity Results

Third, the material substance component consists of 8 indicators, namely 1) The use of primary navigation and hyperlinks in interactive multimedia is functioning correctly, 2) The use of fonts (type and size) of letters in interactive multimedia is proportional, 3) Images, videos, sounds, and animations which is presented in interactive multimedia are already functioning correctly, 4) The combination of colors on the cover and each interactive multimedia slide is proportional, 5) The animation used in interactive multimedia does not slow down the slide show, 6) The cover display on interactive multimedia shows the content, 7) Layout and layout on interactive multimedia are proportional and attractive, 8) Instructions for using interactive multimedia are precise and clear. The data plot values for each indicator of the visual communication display are shown in FIGURE 8.

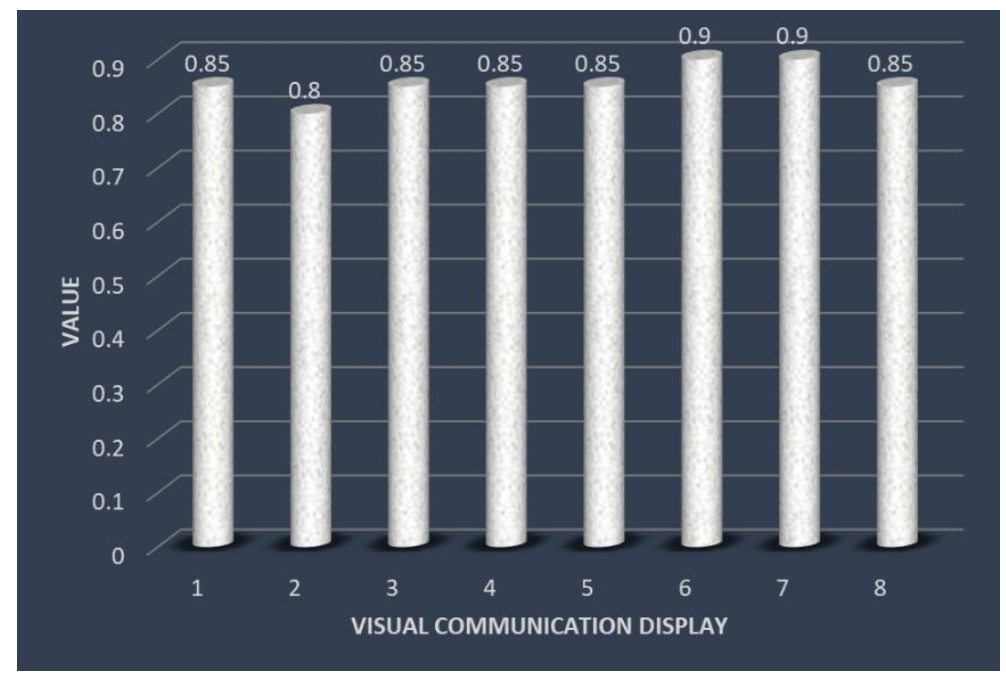

FIGURE 8. Visual communication validity results

FIGURE 8 shows that the indicator value on the visual communication display ranges from 0.85 to 0.90 . Of the eight indicators, seven are classified as very valid, ranging from 0.85 to 0.90 , and the indicator is classified as valid as 0.80 . The average validation value on the material substance indicator is 0.86 . Thus the validation value of the material substance is classified as very valid.

Fourth, the material substance component consists of 3 indicators, namely (1) interactive multimedia is interactive to provide feedback to users, (2) interactive multimedia uses supporting software, (3) interactive multimedia is the original work. The data plot values for each indicator of software utilization are shown in FIGURE 9. 


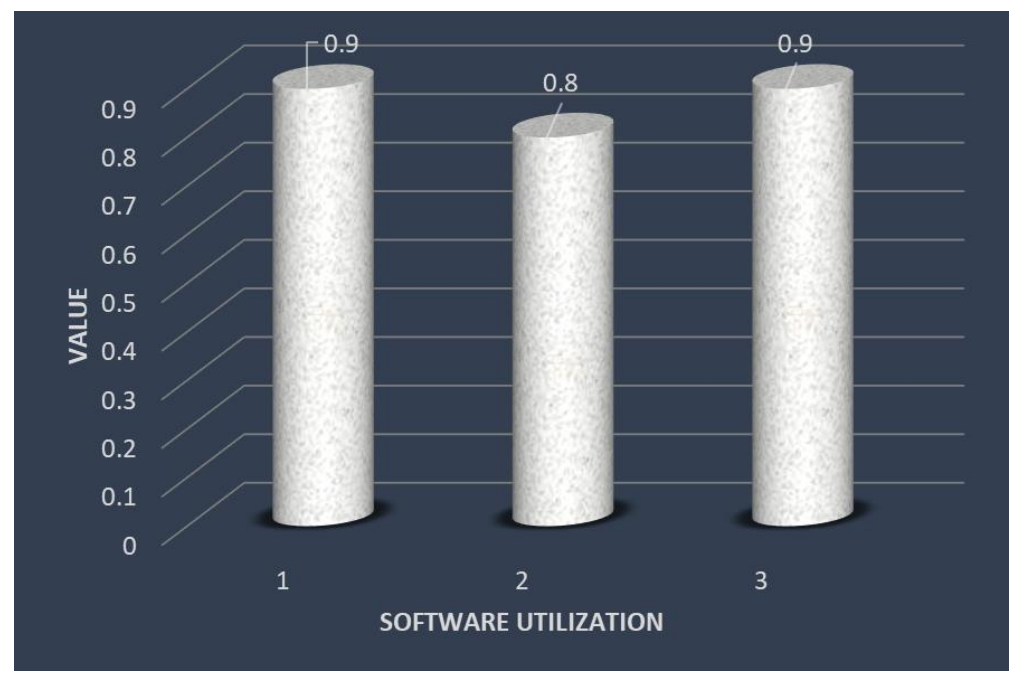

FIGURE 9. Software utilization validity results

FIGURE 9 shows that the indicator value on software utilization ranges from 0.8 to 0.9 . Of the three indicators, two indicators are classified as very valid. The average validation value on the material substance indicator is 0.87 . Thus the validation value of the material substance is classified as very valid.

The average value of each assessment component on interactive multimedia is based on the cognitive conflict in improving students' $4 \mathrm{C}$ comprehension and skills on static fluid material. Interactive multimedia contains four elements of ICT-based teaching material development, namely 1) Material substance, 2) Learning design, 3) Visual communication display, 4) Software Utilization. The results of the validity value plot are shown in FIGURE 10.

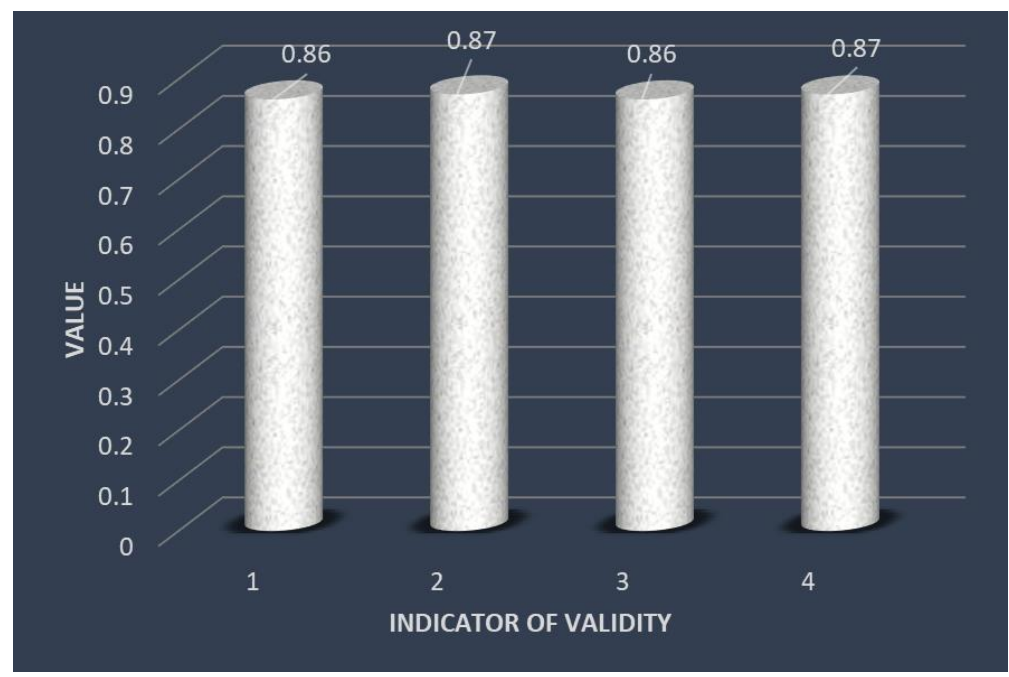

FIGURE 10. The average result of the validation indicators

FIGURE 10 shows that the validation indicator values are $0.86,0.87,0.86$, and 0.87 . The average value of the indicator's overall validity is 0.865 . From this value, overall indicators on interactive multimedia are classified as very valid. Interactive multimedia validation results obtained suggestions from experts to be revised. Expert advice is used to improve the feasibility of interactive multimedia created.

\section{Discussion}

Based on the results of preliminary research, the teacher's learning is not following the demands of the 2013 curriculum. The results obtained are the same as previous research, which shows that education is still teacher-centered (Mufit 2021; Delvia 2021; Luthfi 2021). The teacher-centered 
learning process results in low student understanding, untrained 4C skills, and misconceptions (Sholihat 2017). The journal analysis results also showed students who did not understand the concepts and misconceptions in the high static fluid material. The results obtained were the same as previous studies in that the student's understanding of concepts on static fluid material was still low (Annisa 2020).

The prototype phase has two stages, namely self-evaluation and expert review. Researchers examined all parts of interactive multimedia created and personally assessed at the self-evaluation stage. After the self-evaluation result is declared valid, continue with the expert's review. Product validation by experts contains four estimated indicators.

The first indicator is the substance of the material. On the validation of the material, obtained validation results are very valid. These results show the material contained in the interactive multimedia has fulfilled the standards. The results obtained are the same as previous studies that the material must be designed according to the standard of learning objectives (Khairunnisa 2018). The second indicator is the learning design. This section implements cognitive conflict-based learning models, trains 4C skills, and integrates virtual labs. The results of validating learning design indicators are classified as very valid categories.

The third indicator is the display and navigation. The validation results in the navigation view section are very valid. Navigation of buttons and commands on interactive multimedia goes well. This result follows previous research that states that the appearance of the teaching material will make the user interested in using it (Annisa 2020). The fourth indicator is the utilization of software. The creation of this interactive multimedia involves a variety of software in making it an android application. The validation result of this stage is very valid.

The validation of the four indicators on the interactive multimedia as a whole is very valid in line with previous research explaining that cognitive conflict-based learning models can mediate misconceptions and improve understanding of student concepts (Mufit 2020). Interactive multimedia helps students understand concepts more easily (Nulhakim 2020). The use of interactive multimedia in the learning process can improve the understanding of student concepts (Gunawan et al. 2016). Interactive multimedia products that have been valid can be tested on students to see the practicality of the products that have been developed (Ilahi 2021)

Meanwhile, in this study, interactive multimedia uses the adobe animate cc 2019 application which strongly supports student interactivity as android smartphone users. The interactive multimedia prototype based on cognitive conflict designed to improve understanding of $4 \mathrm{C}$ concepts and skills is in the very valid category. It can be continued at the practical and effective test stage.

\section{CONCLUSION}

Interactive multimedia has been designed to improve students' understanding of concepts and $4 \mathrm{C}$ skills. Interactive multimedia is designed using the Adobe Animate CC 2019 application and contains four syntaxes of cognitive conflict-based learning models, namely (1) Activation of preconceptions and misconceptions, (2) Presentation of cognitive conflicts, (3) Discovery of concepts and similarities, (4) Reflection. Interactive multimedia is valid in four aspects, namely (1) material substance, (2) learning design, (3) visual communication display, (4) software utilization. The researcher can test interactive multimedia based on cognitive conflict for its practicality and effectiveness for further researchers. It can be used as alternative teaching materials in improving students' understanding of $4 \mathrm{C}$ concepts and skills on static fluid.

\section{REFERENCES}

Annisa, F, Mufit, F \& Asrizal, A 2020, 'Analisis Validitas dan Praktitikalitas Lembar Kerja Siswa Berbasi Konflik Kognitif Pada Materi Gerak Lurus dan Gerak Parabola', Pillar Of Physics Education: Jurnal Berkala Ilmiah Pendidikan Fisika, vol. 13 no. 1, pp. 233-240.

Delvia, T, Mufit, F \& Bustari, M 2020, 'Design and Validity of Physics Teaching Materials Based on Cognitive Conflict Integrated Virtual Laboratory in Atomic Nucleus', Pillar Of Physics Education: Jurnal Berkala Ilmiah Pendidikan Fisika, vol. 14 no. 1. 
Festiyed, F, Djamas, D \& Ramli, R 2019, 'Learning model based on discovery learning equipped with interactive multimedia teaching materials assisted by games to improve critical thinking skills of high school students', Journal of Physics: Conference Series, IOP Publishing, vol. 1185, p. 012054.

Green, T \& Labrecque, J, 2017, 'Interactivity Basics. In: Beginning Adobe Animate CC', Apress: Berkeley, CA.

Green, T \& Labrecque, J 2017, 'Learning the Animate CC Interface', In: Beginning Adobe Animate CC, Apress: Berkeley, CA, pp. 1-56.

Gunawan, G, Harjono, A \& Imran, I 2016, 'Pengaruh Multimedia Interaktif dan Gaya Belajar terhadap Penguasaan Konsep Kalor Siswa', Jurnal Pendidikan Fisika Indonesia, vol. 12 no. 2, pp. 118-125.

Ilahi, TDW, Mufit, F, Hidayati, H \& Afrizon, R 2021, 'Disain dan Validitas Multimedia Interaktif Berbasis Konflik Kognitif pada Materi Vektor untuk Kelas X SMA/MA', Jurnal Penelitian Pembelajaran Fisika, vol. 12, no. 2, pp. 182-195.

Kemendiknas 2010, 'Panduan Pengembangan Bahan Ajar Berbasis TIK. Jakarta', Direktur Pembinaan SMA.

Khairunnisa, H \& Kamus, Z 2018, 'Analisis Efektivitas Pengembangan Bahan Ajar Fisika dengan Konten Kecerdasan Sosial pada Materi Gerak Parabola, Gerak Melingkar dan Hukum Newton untuk Kelas X SMA', Pillar Of Physics Education: Jurnal Berkala Ilmiah Pendidikan Fisika, vol. 11, no. 2, pp. 121-128.

Luthfi, I, Mufit, F \& Putri, MRN 2021, 'Design of Physical Teaching Materials Based on Cognitive Conflict Learning in Direct Current Electricity Integrating Virtual Laboratory', Pillar Of Physics Education: Jurnal Berkala Ilmiah Pendidikan Fisika, vol. 13, no. 4.

Mufit, F \& Fauzan, A 2019, 'Model Pembelajaran Berbasis Konflik Kognitif (PbKK) Disertai Penerapan untuk Remediasi Miskonsepsi pada Sains dan Matematika', Malang: CV. IRDH.

Mufit, F \& Puspitasari, R 2020, 'Meta-analysis of the effect of cognitive conflict on physics learning', Jurnal Penelitian \& Pengembangan Pendidikan Fisika, vol. 6, no. 2, pp. 267-278.

Mufit, F, Festiyed, F, Fauzan, A \& Lufri, L 2018, 'Impact of learning model based on cognitive conflict toward student's conceptual understanding', IOP Conference Series: Materials Science and Engineering, vol. 335, p. 012072.

Nulhakim, L, Setiawan, FR \& Saefullah, A 2020 , 'Improving Students' Creative Thinking Skills Using Problem-Based Learning (PBL) Models Assisted by Interactive Multimedia', Jurnal Penelitian \& Pengembangan Pendidikan Fisika, vol. 6 no. 1, pp. 9-16.

Plomp, T 2013, 'Educational Design Research: A Introduction', Educational Design Research, pp. 1051.

Prastiwi, VD, Parno, P \& Wisodo, H 2018, 'Identifikasi pemahaman konsep dan penalaran ilmiah siswa SMA pada materi fluida statis', Momentum: Physics Education Journal.

Retnawati, H 2016, 'Analisis Kuantitatif Instrumen Penelitian', Parama Publishing, Yogyakarta.

Riduwan 2012, 'Pengantar Statistika (Untuk Penelitian Pendidikan, Sosial, Ekonomi, Komunikasi Dan Bisnis)', Alfabeta: Bandung.

Saputra, O, Setiawan, A \& Rusdiana, D 2019, 'Identification of student misconception about static fluid', Journal of Physics: Conference Series, vol. 1157, p. 32069.

Sholihat, FN, Samsudin, A \& Nugraha, MG 2017, 'Identifikasi Miskonsepsi dan Penyebab Miskonsepsi Siswa Menggunakan Four-Tier Diagnostic Test Pada Sub-Materi Fluida Dinamik: Azas Kontinuitas', Jurnal Penelitian \& Pengembangan Pendidikan Fisika, vol. 3 no. 2, pp. 175 180.

Wahyuni, S 2019, 'Indetifikasi Miskonsepsi Peserta Didik pada Konsep Fluida Statis di Kelas XI SMAN 5 Banda Aceh', UIN Ar-Raniry, Banda Aceh. 
Wartono, Saifullah, AM \& Sugiyanto, S 2017, 'Identifikasi Miskonsepsi Siswa Kelas X pada Materi Fluida Statis dengan Instrumen Diagnostik Three-Tier', Jurnal Pendidikan Dan Pembelajaran (JPP), vol. 23, no. 1, pp. 20-26.

Widada, RA 2018, 'Perancangan Media Pembelajaran Fisika SMP Berbasis Multimedia Interaktif', IT CIDA, vol. 3, no. 2, pp. 53-68.

Wijaya, EY, Sudjimat, DA, Nyoto, A \& Malang, UN 2016, ‘Transformasi Pendidikan Abad 21 Sebagai Tuntutan Pengembangan Sumber Daya Manusia Di Era Global', Prosiding Seminar Nasional Pendidikan Matematika, vol. 1, pp. 263-278.

Yudhittiara, RF, Hindharto, N \& Mosik, M 2017, 'Identifikasi Miskonsepsi Menggunakan Cri Dan Penyebabnya Pada Materi Mekanika Fluida Kelas XI SMA', UPEJ Unnes Physics Education Journal, vol. 6, no. 2, pp. 81-89.

Zubaidah, S 2016, 'Keterampilan Abad ke-21: Keterampilan yang diajarkan melalui pembelajaran', Seminar Nasional Pendidikan, vol. 2, pp. 1-17. 
